\title{
The influence of body image and gender in adolescent obesity
}

DOI: dx.doi.org/10.22435/hsji.v11i1.3068

\author{
Vita Pertiwi $^{1}$, Balgis ${ }^{2}$, Yusuf Ari Mashuri ${ }^{2}$ \\ ${ }^{1}$ Student in Faculty of Medicine, Universitas Sebelas Maret \\ ${ }^{2}$ Faculty of Medicine, Universitas Sebelas Maret \\ Corresponding author: Vita Pertiwi \\ Email: vitapertiwi96@gmail.com
}

Received: February 11, 2020; Revised: April 2, 2020; Accepted: May 18, 2020.

\begin{abstract}
Abstrak
Latar Belakang: Body image adalah persepsi penampilan fisik diri sendiri. Mispersepsi berat badan pada remaja dapat menyebabkan rasa ketidakpuasan terhadap tubuh dan obesitas pada remaja. Jenis kelamin juga berperan dalam obesitas remaja dan body image. Remaja yang obes memiliki risiko penyakit tidak menular lebih besar dibandingkan remaja dengan berat badan normal. Maka dari itu, penelitian ini bertujuan untuk melihat pengaruh body image dan jenis kelamin pada obesitas di remaja.

Metode: Desain penelitian ini adalah observasional dengan pendekatan cross sectional. Penelitian ini dilakukan pada bulan November 2019 di SMK Negeri 9 Surakarta. Jumlah subjek dari penelitian ini sebanyak 57 siswa yang dipilih dengan cara two stage sampling. Body image dan obesitas dinilai melalui kuesioner MBSRQ-AS, Grafik IMT berdasarkan usia dan lingkar pinggang. Data yang telah terkumpul diolah dengan independent T-test, fisher exact test, uji regresi logistik dengan nilai signifikansi p <0,05.

Hasil: Terdapat perbedaan yang signifikan dalam skor body image antara kelompok obesitas dan non obesitas $(p=0,006)$ dan rata - rata skor laki-laki lebih tinggi dibandingkan perempuan. Selain itu, laki-laki memiliki skor lebih tinggi dalam setiap aspek body image dibandingkan perempuan. Hubungan signifikan juga ditemukan antara body image dan obesitas $(p=0,045)$, dan jenis kelamin dengan obesitas $(p=0,009)$.

Kesimpulan: Ada hubungan yang signifikan antara citra tubuh dan jenis kelamin dengan obesitas pada remaja dan skor citra tubuh berbeda secara signifikan antara kelompok obesitas dan non obesitas dan antara siswa pria dan wanita. (Health Science Journal of Indonesia 2020;11(1):22-6)
\end{abstract}

Kata kunci: body image,obesitas, jenis kelamin, remaja

\begin{abstract}
Background: Body image is a perception of our physical appearance. Weight misperception in adolescent lead to body dissatisfaction and obesity in adolescent. Gender also plays a role in adolescent obesity and body image. Obese adolescents have greater risk of non-communicable diseases than adolescents with normal weight. therefore, this research aims to discover body image and gender influence on adolescent obesity.

Method: This study is an observational design with cross sectional approach. The study was conducted in November 2019 at SMK Negeri 9 Surakarta. The subjects were 57 sophomore that were chosen randomly with simple random sampling. Body image and obesity were measured using MBSRQ-AS questionnaire, BMI for Age Charts and waist circumference. Data was processed by independent T-test, fisher exact test, logistic regression test with significance value $\mathrm{p}<0.05$.
\end{abstract}

Results : There is a significant difference in body image scores between obese and non obese group $(\mathrm{p}=$ $0.006)$ and male students scored higher in every aspect of body image than female students. A significant relationship was found between body image and obesity $(\mathrm{p}=0,045)$, and gender with obesity $(\mathrm{p}=0.009)$.

Conclusion: There is a significant relationship between body image and gender with obesity in adolescents and body image scores differ significantly between obese and non obese group and between male and female students. (Health Science Journal of Indonesia 2020;11(1):22-6)

Keywords: body image, obesity, gender, adolescents 
Obesity defined as an abnormal accumulation of excess fat in adipose tissue that can lead to other health problems and also known as one of the health problems in the world. ${ }^{1}$ Adolescents obesity is a global concern because of its impacts on health and high rate incidence in the world. ${ }^{2}$ In 2016, WHO reported that over 340 million children and adolescents aged 5-19 were obese. ${ }^{3}$ Adolescent's obesity has a greater risk of developing noncommunicable diseases compared to normal weight counterparts and often have psychological and social problems such as self-confidence, misperception on body image, depression, anxiety and discrimination. ${ }^{4}$

Based on Erik Erikson's Physicosocial Development theory, adolescence is the stage of finding an identity. ${ }^{5}$ This makes adolescents is a crucial period in forming body image. ${ }^{6}$ Their perception of the ideal body can be influenced by gender, media, ethnics, and social interaction. ${ }^{7}$ Ideal body perception between female and male is different. Female tends to want a thin body but male likes bulky body more. ${ }^{8}$ Media is responsible for the thin body as an ideal body image. Thin ideal body stigma causes obese adolescents to tend to feel dissatisfied with their body or called body dissatisfaction. ${ }^{9}$ This weight misperception can cause body dissatisfaction that induces maladaptive eating behavior in adolescents. ${ }^{10}$ The prevalence of weight misperception also increases along with the prevalence of adolescent obesity. ${ }^{11}$

This study aims to analyze the relationship between body image and gender with obesity in adolescents. This research is also useful to increase knowledge related to body image and obesity and can be used as a source to educate teenagers in evaluating their bodies and using a body image approach to promote adolescents obesity prevention.

\section{METHODS}

\section{Study design}

This study is an observational analytic design with a cross sectional approach.

\section{Study subjects}

The study takes place at SMK Negeri 9 Surakarta which is under Banyuanyar Public Health Center territory work area in November 2019. Subjects of this study were sophomore in multimedia and visual communication design class that were chosen randomly by simple random sampling. The sample size was calculated using the Lemeshow formula and 55 samples were obtained. This study also had an ethical clearance from Faculty of Medicine, Universitas Sebelas Maret, number 331/UN27.06/ $\mathrm{KEPK} / \mathrm{EC} / 2019$.

\section{Study variables}

The dependent variable was obesity. In this study, obesity was measured by using WHO's BMI for age chart and measuring tape. The measuring tape was used for measuring waist circumference. Measurement of waist circumference and BMI is needed in this study to increase the sensitivity and specificity. ${ }^{12}$ The cut-offs for obesity in this study were $>+2 \mathrm{SD}$ and/or $>86,45 \mathrm{~cm}$ for male's waist circumference and $>76,50 \mathrm{~cm}$ for female's waist circumference. Adolescent does not have universal cut-offs. Therefore, waist circumference's cut-offs is based on research that was conducted in Indonesia by Mulyasari and Pontang. ${ }^{13}$ Independent variable was body image and gender. Body image is an individual's perception of their physical appearance based on self observation and other's opinions. MBSRQ-AS was used to assess body image. There were five aspects of body image in MBSRQ-AS, appearance evaluation, appearance orientation, overweight preoccupation, body area satisfication, and self-classified weight. Self-classified weight will not be assessed. In this section, the question is a categorical question that can't be scored. This questionnaire consists of appearance orientation, appearance evaluation, overweight preoccupation, and body area satisfication questions with total 34 items, and each item was scored between 1 to 5 . The total score from each individual was divided by total item and then converted to two decimals. Individuals with scored 2,50 or higher belong to body image positive group, but if the score is below 2,50, it will belong in body image negative group.

\section{Data analysis}

Firstly data were analyzed with Kolmogorovsmirnov normality test and Homogeneity test. The data was normal and homogenous. To determine the relationship between 2 variables, the independence T-test, Mann Whitney, and fisher's exact test were used. Independence T-test and Mann Whitney are used to analyze body image and obesity, while fisher's exact test is used to analyze gender and obesity. To evaluate the two independent variables on influencing the dependent variable this study used logistic regression. In logistic regression, two 
variables can be included simultaneously to get an adjusted odds ratio. All of these tests was run by SPSS 24 Software for Windows.

\section{RESULTS}

Characteristics subject from this study were categorized into several variables, like age, gender, physical activity, and parents socioeconomic conditions. Based on gender and age, there were 40 male students and 17 female students with age ranges from 16 to 18 years old (Table 1). According to table 1, total of 35 students had moderate physical activity, and based on the distribution of parents' socioeconomic conditions, $59.6 \%$ were reported to have low income category and based on their obesity status, 13 students belong to obese groups and 44 in non-obese groups.

According to a univariate analysis of body image, all of the subjects in this study were reported to have a positive body image $(\geq 2,50)$. But there were significant body image score differences between male and female students where male student scores higher than the female students (Table 2). This correlation was tested using an independent T-test.

Table 1. Subject's characteristic

\begin{tabular}{|c|c|c|}
\hline Characteristics & $\mathrm{N}$ & $\%$ \\
\hline \multicolumn{3}{|l|}{ Gender } \\
\hline Male & 40 & 70,2 \\
\hline Female & 17 & 29,8 \\
\hline \multicolumn{3}{|l|}{ Age } \\
\hline 16 years old & 39 & 68,4 \\
\hline 17 years old & 17 & 29,8 \\
\hline 18 years old & 1 & 1,8 \\
\hline \multicolumn{3}{|l|}{ Physical Activity } \\
\hline Low & 22 & 38,6 \\
\hline Moderate & 35 & 61,4 \\
\hline \multicolumn{3}{|l|}{ Parents Income } \\
\hline Low & 34 & 59,6 \\
\hline High & 23 & 40,4 \\
\hline \multicolumn{3}{|l|}{ Obesity } \\
\hline Obese & 13 & 22,8 \\
\hline Non Obese & 44 & 77,2 \\
\hline
\end{tabular}

Independent T-test was used to evaluate the correlations between body image and obesity and obtained $\mathrm{p}$ value $=0.006$ which means there are significant differences in body image mean scores between the obese and non-obese groups (Table 4). The obese group has a smaller mean body image score than non-obese group.
Table 2. Gender, obesity and body image scores

\begin{tabular}{|c|c|c|c|c|c|c|}
\hline & \multicolumn{6}{|c|}{ Body image scores } \\
\hline & \multirow{2}{*}{ Min } & \multirow{2}{*}{ Max } & \multirow{2}{*}{ Mean } & \multicolumn{2}{|c|}{$95 \% \mathrm{CI}$} & \multirow[t]{2}{*}{$\mathrm{P}$} \\
\hline & & & & Low-er & Upp-er & \\
\hline \multicolumn{7}{|l|}{ Gender } \\
\hline Male & 2,71 & 4,19 & 3,22 & \multirow{2}{*}{0,03} & \multirow{2}{*}{0,39} & \multirow{2}{*}{0,03} \\
\hline Female & 2,61 & 3,48 & 3,00 & & & \\
\hline \multicolumn{7}{|l|}{ Obesity } \\
\hline Obese & 2,71 & 3,39 & 2,94 & \multirow{2}{*}{$-0,475$} & \multirow{2}{*}{$-0,083$} & \multirow{2}{*}{0,006} \\
\hline Non Obese & 2,74 & 4,19 & 3,22 & & & \\
\hline
\end{tabular}

In addition to body image, gender is also associated with obesity. Based on the fisher's exact test results showed the value of $p=0.001$ (Table 5). Therefore, it can be concluded that gender variables have a significant relationship with obesity.

Table 3. Correlation between body image scores and obesity

\begin{tabular}{|c|c|c|c|}
\hline & \multicolumn{2}{|c|}{ Gender } & \multirow{2}{*}{$P$} \\
\hline & Male & Female & \\
\hline Obese & 4 & 9 & \multirow{2}{*}{$-0,001$} \\
\hline Non obese & 36 & 8 & \\
\hline
\end{tabular}

This study assessed four body image aspects in MBSRQAS questionnaire. There are appearance evaluation, appearance orientation, overweight preoccupation, and body area statisfication. Appearance evaluation shows how individuals see their overall appearance. Based on table 6, the subject of this study have a high score in this section. Meanwhile, appearance orientation will show the subject's concern about their body through the effort that they made to change and it was reported that female students and the obese groups have a bigger tendency to do something about their appearance than male students and non-obese group.

Table 4. Independent T-Test and Mann Whitney results of body image aspect scores with obesity and gender

\begin{tabular}{|c|c|c|c|c|c|c|}
\hline \multirow[b]{2}{*}{ Body image } & \multicolumn{2}{|c|}{ Obesity } & \multirow[b]{2}{*}{$P$} & \multicolumn{2}{|c|}{ Gender } & \multirow[b]{2}{*}{$P$} \\
\hline & Obese & $\begin{array}{l}\text { Non } \\
\text { obese }\end{array}$ & & Male & Female & \\
\hline $\begin{array}{l}\text { Appearence } \\
\text { evaluative }\end{array}$ & 3,3 & 3,38 & 0,58 & 3,38 & 3,30 & 0,61 \\
\hline $\begin{array}{l}\text { Appearence } \\
\text { orientation }\end{array}$ & 2,73 & 2,95 & 0,09 & 2,94 & 2,83 & 0,38 \\
\hline $\begin{array}{l}\text { Overweight } \\
\text { preoccupation }\end{array}$ & 2,67 & 3,34 & 0,01 & 3,30 & 2,98 & 0,21 \\
\hline $\begin{array}{l}\text { Body area } \\
\text { statisfication* }\end{array}$ & 3,03 & 3,42 & 0,074 & 3,46 & 3,05 & $\mathbf{0 , 0 3}$ \\
\hline
\end{tabular}

Overweight preoccupation is individual's fear becoming fat and body area statisfication is a statisfication of particular body parts. Table 6 showed 
that overweight preoccupation has a significant relationship with obesity which means the obese group is reported to have greater weight gain anxiety. Furthermore, the body area statisfication aspect has significant relationship with gender. It can be concluded that male and female have a different body parts preference.

Body image, gender, and obesity were analyzed using multivariate logistic regression analysis. The logistic regression analysis obtained $\mathrm{p}$ value $=0.045$ for body image and 0.009 for gender. body image's adjusted odds ratio is 0.035 , which means higher body image scores will reduce the possibility of getting obese. From table 7, gender's adjusted odds ratio is 7.43 and it shows that female students have a higher risk to become obese than male students.

Table 5. Association between Body Image, Gender and Obesity

\begin{tabular}{lcccc}
\hline Variables & \multirow{2}{*}{$\begin{array}{c}\text { Odds Ratio } \\
\text { (OR) }\end{array}$} & \multicolumn{2}{c}{ CI 95\% } & $\boldsymbol{P}$ \\
\cline { 3 - 4 } & 0,035 & 0,001 & 0,928 & $\mathbf{0 , 0 4 5}$ \\
\hline Body Image & & & & \\
\cline { 1 - 1 } Gender & 7,143 & 1,617 & 31,554 & $\mathbf{0 , 0 0 9}$ \\
\cline { 1 - 1 } Male (0) & & & & \\
\hline Female (1) & & & &
\end{tabular}

\section{DISCUSSIONS}

Body image scores and gender have a significant correlation with obesity. An adjusted odds ratio of body image score is 0.035 , which means respondent with low body image scores has a higher obesity risk than respondent with high body image scores. Based on gender's adjusted odds ratio, it is known that female respondents are at risk 7,143 times becoming obese. Body image can influence obesity through weight misperception. This misperception is divided into underestimation and overestimation. Underestimation is found in an obese who does not consider themselves obese. $^{14}$ Overestimation can usually be found in someone who has normal weight but feeling fat. Overestimation and underestimation of body weight can cause inappropriate eating behavior and cause obesity. Negative body image or dissatisfaction with the body can cause inappropriate eating behavior. ${ }^{15}$ Another factor that can affect obesity in this study is gender. Female was reported to have a higher risk of becoming obese because of the increase of estrogen hormone in female. ${ }^{16}$

Body image scores differ between male and female respondents. These differences can be caused by the fact that men tend to be more confident and have better self-concept (a person's perception of their appearance, abilities, and role) compared to women. ${ }^{17}$ A study by Jain \& Tiwari found that the boy's perception about the ideal self not only came from a muscular body but also the ability to solve problems and good manners. ${ }^{18}$ Men's physical changes at puberty such as the formation of muscles and enlargement of shoulder width is in accordance with the ideal idea of the masculine body. Therefore, adolescent boys tend to be more satisfied with their bodies. ${ }^{19}$ Another alike results were found in research conducted in Indonesia that men tend to have higher body image scores compared to women. ${ }^{20}$

In spite of having different body image score, all respondent in this study is classified as body image positive. Factors that influencing body image scores in this study are age, gender, and intrapersonal interaction. Most respondent in this study is at age 16 and body disastification towards body increases with age. ${ }^{21}$ Body dissatisfaction most often appears at the age of 18 years old to 25 years old and tends to persist or worsen with age. ${ }^{22}$ Based on the section self-classified weight in MBSRQ-AS questionnaire, the majority of respondents $(38.6 \%)$ felt that their bodies were considered thin by others. This shows that the respondent's environment did not give negative comments on his appearance. Interpersonal relationships with family and peers can affect body image. ${ }^{23}$ Comments from family and peers about appearance is one of the factors that can prevent negative body image in adolescent girls. ${ }^{24}$ Majority student in SMKN 9 Surakarta is a male student. Male tends to have a positive body image when they were a teenager. This uneven ratio between male and female student influence peer interaction and eventually prevent female student having body image negative.

In conclusion, it can be concluded that student with low body image score and female more likely to become obese and obese student tends to have a low body image score. An intervention strategy to prevent adolescent obesity may also be based on body image, especially by using the overweight preoccupation aspect.

\section{Acknowledgments}

The author would like expressed a gratitude and highest appreciation to Ari Natalia Probandari, dr., MPH, Ph.D, Vitri Widyaningsih, dr., MS and Heni Hastuti, dr., MPH for their advice and direction from the research plan until the completion of the writing of this research. The author would also like to thank SMK N 9 Surakarta for their participation. 


\section{REFERENCES}

1. Chandrashekar N, Pagadala P, Nerella S, Babu MR. Comparative study of body mass index and pulmonary functions between overweight and normal weight women. Natl J Physiol Pharm Pharmacol. 2018;8(8):1124-7.

2. Taylor SA, Borzutzky C, Jasik BC, Mihalopoulos NL, Smith-Barron K, Woolford SJ, et al. Preventing and treating adolescent obesity : a position paper of the society for adolescent health and medicine. J Adolesc Health. 2016;59(5):602-6.

3. WHO. Obesity and overweight [Internet]. WHO. 2018 [cited 2019 May 5]. Available from : https://www. who.int/news-room/fact-sheets/detail/obesity-andoverweight.

4. The American College of Obstetricians and Gynecologist. ACOG committee opinion obesity in adolescents number 714 [Internet]. ACOG. 2017. [cited 2019 May 17]. Available from : https://m.acog.org.

5. Javellana G. Influence of media on body image satisfaction among adolescents. Asia Pacific Journal of Education, Arts and Sciences. 2014;1(1):95-101.

6. Voelker DK, Reel JJ, GreenleafC. Weight status and body image perceptions in adolescent: current perspectives. Adolesc. Health, Med. Ther. 2015;6:149-58.

7. Puraikalan Y. Obesity: perceptions of body image and obesity among cross culture: a review. Obes Res Open J. 2018;5(1):1-4.

8. Kilpela LS, Becker CB, Wesley N, Tiffany S. Body image in adult women: moving beyond the younger years. Adv Eat Disord. 2015;3(2):144-64.

9. Yan H, Wu Y, Oniffrey T, Brinkley J, Zhang R, Zhang X, et al. Body weight misperception and its association with unhealthy eating behaviors among adolescents in China. Int. J. Environ. Res. Pulic Health. 2018;15(936):1-11

10. Haynes A, Kersbergen I, Sutin A, Daly M, Robinson, E. A systematic review of the relationship between weight status perceptions and weight loss attempts, strategies, behaviours and outcomes'. Obes Rev. 2018;19:347-63.

11. Angoorani P, Heshmat R, Ejtahed HS, Qorbani M, Motlagh ME, Ziaodini $\mathrm{H}$, et al. Body weight misperception and health-related factors among Iranian children and adolescents: the CASPIAN-V study. J. Pediatr. Endocrinol. Metab. 2017;30(10):1033-40.

12. Yiyang $C$, Zhang $Y$, Wang L. Low diagnostic accuracy of body mass index-based and waist circumferencebased references of childhood overweight and obesity in identifying overfat among Chinese children and adolescents. BioMed Res. Int. 2018;2018:1-9.

13. Mulyasari I, Pontang G. Waist circumference and waist-to-height ratio as indicators for excess adiposity in Indonesian adolescents. Jurnal Gizi Pangan. 2018;13(3):131-6.

14. Jáuregui-Lobera I, Iglesias AC, Sánchez JA, Arispon JC, Andrades CR, Herrero GM, et al. Self-perception of weight and physical fitness, body image perception, control weight behaviors and eating behaviors in adolescents. Nutr. Hosp. 2018;3(5):1115-23.

15. Brytek-Matera A, Czepczor-Bernat K, Olejniczak D. Food-related behaviours among individuals with overweight/obesity and normal body weight. Nutr J. 2018;17(93):1-10.

16. Armi MWP, Dwipayana IMP. Perbedaan prevalensi obesitas dan berat badan lebih pada siswa Sekolah Menengah Atas (SMA) Negeri antara daerah urban dan rural di Kabupaten Gianyar. E-Journal Medika. 2018;7(2):72-6. Indonesian.

17. You S, Shin, K. Body esteem among Korean adolescent boys and girls. Sustainability. 2019;11(2051):1-13.

18. Jain P, Tiwari GP. Positive body image and general health: a mixed methods study. Int J Indian Psychol. 2016;4(1):34-51.

19. Agam R, Tamir S, Moria. Gender differences in respect to self-esteem and body image as well as response to adolescents' school-based. J Psychol Clin Psychiatry. 2019;2(5):1-7.

20. Swami V, Jaafar JL. Factor structure of the body appreciation scale among Indonesian women and men: further evidence of a two-factor solution in a non-Western population. Body Image. 2012;9:539-42.

21. Bucchianeri MM, Arikian AJ, Hannan PJ, Eisenberg ME, Neumark-Sztainer D. Body dissatisfaction from adolescence to young adulthood: findings from a 10Year Longitudinal Study. Body Image. 2013;10(1):1-15.

22. Smith HL. Ageing, anxiety and appearance: exploring the body image of women in midlife. Journal of aesthetic nursing. 2014;3(3):134-5.

23. Michael SL, Kathryn W, Marc NE, Patricia JD, David EK, Jan LW, et al. Parental and peer factors associated with body image discrepancy among fifth-grade boys and girls. J Youth Adolesc. 2014;43(1):15-29.

24. Frisén A, Holmqvist K. What characterizes early adolescents with a positive body image? a qualitative investigation of Swedish girls and boys. Body image. 2010;7:205-12 